\title{
Teori Penjulukan
}

\section{Dadi Ahmadi dan Aliyah Nur'aini H.}

\begin{abstract}
Labelling theory, famously associated with Howard Becker, was resulted from deviation studies which flourished in the late years of 1950s. Labelling theory, as part of interaction symbolic school of thought, assumed deviation as interactional function between deviants and non-deviants, rather than individual inherent characteristic. Labelling theory consisted of four tenets: (1) Social label for particular action; (2) criminal act is resulted from social rules;

(2) social control is worsening criminal problems; and (4) there are interrelated bonds within people who being labeled and their counterparts who give them any label. Media, for some ideological reasons, implied labeling theory in their narration which acted as a mean for social construction.
\end{abstract}

Kata kunci: teori penjulukan, interaksionisme simbolik, kontrol sosial

"if men define situations as real, they are real in their consequences" (William I Thomas) ${ }^{1}$

\section{Latar Belakang Teori Penjulukan}

Labelling theory atau teori penjulukan dapat disebut juga sebagai teori reaksi sosial. Teori ini diilhami terutama oleh teori interaksi simbolik dari George Herbert Mead dalam bukunya Mind, Self, and Society (1934), hanya saja diterapkan dalam dunia orang-orang yang menyimpang (devians)

Menurut teori interaksi simbolik, manusia belajar memainkan berbagai peran dan mengasumsikan identitas yang relevan dengan peran-peran ini, terlibat dalam kegiatan yang menunjukkan kepada satu sama lainnya siapa dan apa mereka, serta mendefinisikan situasi-situasi yang mereka masuki. Perilaku mereka berlangsung dalam konteks sosial, makna, dan definisi situasi tersebut.

Teori penjulukan sering diasosiasikan dengan Howard Becker yang memperkenalkannya pada $1963^{2}$.

\begin{abstract}
"deviasi bukanlah merupakan kualitas dari perilaku seseorang, namun lebih merupakan konsekuensi dari pelaksanaan aturan yang ditetapkan oleh kekuasaan dan sanksi yang dijatuhkan. Seorang deviasi adalah orang yang mendapatkan label dan menjalankan perilaku deviasi sesuai dengan label yang diberikan oranorang kepadanya"
\end{abstract}

Teori penjulukan muncul sebagai akibat dari studi mengenai deviasi (penyimpangan perilaku), sekitar akhir tahun 50 an dan awal tahun 60 an, dan merupakan suatu penolakan terhadap teori konsensus atau teori struktural fungsional yang memahami deviasi sebagai perilaku yang menyimpang yang dapat mengganggu normanorma sosial di masyarakat. Teori penjulukan menolak pendekatan ini. Menurut teori penjulukan, deviasi bukanlah sebuah cara berperilaku, melainkan "nama" yang di berikan kepada sesuatu, sebuah label/penandaan. Ini menandakan bahwa deviasi bukanlah sesuatu yang inheren dengan perilaku melainkan suatu outcome bagaimana individu dan perilaku mereka dilabel. 


\section{Awal Perkembangannya}

George Herbert Mead dalam bukunya Mind, Self, and Society (1934), teori interaksi simbolik diterapkan dalam dunia orang-orang yang menyimpang (devians).

Frank Tannenbaum $(1938)^{3}$, mungkin merupakan orang yang secara khusus mulai merintis konsep teori penjulukan. Konsep utamanya adalah dramatisasi iblis. Tannenbaum menyatakan bahwa seseorang akan berperilaku sesuai dengan yang digambarkan oleh orang lain.

Edwin M. Lemert (1951)4, dianggap sebagai penemu pendekatan "reaksi sosial". Pendekatan ini membedakan antara perilaku menyimpang pertama (primary deviance) dan perilaku menyimpang kedua (secondary deviance). Perilaku menyimpang pertama disebabkan berbagai macam alasan, bisa karena faktor biologis, psikologis, ataupun sosiologis. Sedangkan perilaku menyimpang kedua, atau deviasi intensif, merupakan suatu penerjemahan akan konsep bertahan, menyerang, dan adaptasi pada masalah yang disebabkan oleh reaksi sosial pada perilaku pertama. Reaksi sosial sangat penting untuk dipelajari terutama ketika para ahli mulai mempelajari toleransi masyarakat. Para ahli yang mengemukakan teori reaksi sosial sering menganggap sama dengan para ahli dari teori fungsional, di mana proses didefinisikan sebagai perilaku yang sangat penting bagi solidaritas sosial. Terkadang, ini disebut sebagai "Kepanikan Moral (Moral Panics) (Goode \& Ben-yehuda, 1994).

Howard S. Becker (1963), dianggap sebagai penemu teori penjulukan dengan pernyataan "Moral Enterpreuner" untuk menggambarkan orang yang menyatakan dirinya untuk melanggar peraturan hukum dengan menjadikan diri mereka sebagai kriminal. Perilaku yang melanggar hukum/ aturan ini bukanlah yang difokuskan oleh teori penjulukan, melainkan ketika penjulukan tersebut mengenai orang-orang yang tidak bersalah dituduh dan diperlakukan seolah-olah devians oleh sistem hukum.

Kebanyakan teori penjulukan meyakini bahwa sistem telah menjadi bias pada masyarakat kalangan menengah ke bawah dan statistik FBI pun menunjukkan angka yang demikian, sehingga dapat menimbulkan anggapan bias yang menyudutkan, hingga akhirnya menjadi penjulukan sosial.

Menjadi seorang kriminal merupakan status yang berat. Ini akan memengaruhi, bila para kriminil berada di tengah masyarakat dan diidentifikasi oleh publik sebagai pelaku kejahatan yang sudah pasti jahat. Publik tidak lagi mengidentifikasi bagaimana asal mereka, orang tua ataupun pekerjaan mereka, selama mereka adalah pelaku kriminal, maka selamanya mereka adalah kriminal. Keadaan ini membuat orang yang dijuluki tersebut menjadi tidak nyaman. Tekanan publik kepada mereka bahwa mereka adalah seorang devians, justru akan membuat mereka menjadi seorang devians atau juga semakin mengokohkan mereka untuk menjadi devians yang sebenarnya.

Becker mengklaim, bahwa kelompok sosial menciptakan penyimpangan (deviasi) dengan membuat aturan mendasar kepada orang-orang tertentu dan memberikan label mereka sebagai orang luar. Menurut Becker, dalam Study Sociology of Deviance, setelah individu mendapat julukan menyimpang, maka mereka akan terus menyimpang dan menjadi sulit untuk melepaskan julukan tersebut karena orang lain melihatnya dengan status individu menunjuk orang luar (Outsiders).

Ini menunjukkan bahwa ketika kita mempelajari devians, seseorang tidak harus menerima penyimpangan mereka sebagaimana adanya karena seseorang menganggap orang-orang tersebut benar telah melakukan penyimpangan atau melanggar beberapa aturan, karena proses teori penjulukan tidak sempurna. Penjulukan penyimpang tidak perlu berarti bahwa individu telah melakukan penyimpangan di masa lalu.

Becker juga menyatakan bahwa teori penjulukan memusatkan kajian terhadap reaksi orang lain (di luar dirinya) dan pengaruh yang ditimbulkan sebagai akibat untuk kemudian menghasilkan penyimpangan. Becker menguatkan bahwa deviasi bukanlah suatu properti yang melekat 
pada bentuk tingkah laku tertentu, tetapi properti yang digunakan oleh individu untuk berperilaku.

\section{Asumsi Dasar Teori Penjulukan}

Labelling adalah proses melabel seseorang. Label, menurut A Handbook for The Study of Mental Health, adalah sebuah definisi yang ketika diberikan pada seseorang akan menjadi identitas diri orang tersebut, dan menjelaskan orang dengan tipe bagaimanakah dia. Dengan memberikan label pada diri seseorang, kita cenderung melihat dia secara keseluruhan kepribadiannya, dan bukan pada perilakunya satu per satu.

Teori penjulukan, secara sederhana, hanya menyatakan dua hal. Pertama, orang berperilaku normal atau tiak normal, menyimpang atau tidak menyimpang, tergantung pada bagaimana orang lain menilainya. Penilaian itu ditentukan oleh kategorisasi yang sudah melekat pada pemikiran orang lain. Segala sesuatu yang dianggap tidak termasuk ke dalam kategori-kategori yang sudah dianggap baku oleh masyarakat (dinamakan residual), otomatis akan dikatakan menyimpang (seorang devians). Kedua, penilaian itu berubah dari waktu ke waktu, sehingga orang yang katakanlah hari ini dinyatakan sakit bisa dinyatakan sehat (dengan gejala yang sama) beberapa tahun kemudian, atau sebaliknya.

Ketika seseorang mendapatkan penjulukan yang mengarah ke arah kejahatan atau perilaku kriminal, maka orang tersebut dapat menjadi "awas" untuk melihat sisi negatif mereka (misalnya seperti orang yang diberi julukan nakal, kriminal, dan lain-lain). Teori penjulukan lebih memfokuskan dirinya untuk memahami kenakalan remaja karena ini terjadi sepanjang waktu ketika remaja berusaha untuk membentuk identitasnya. Calhoun menyatakan, teori penjulukan juga membantu dalam menjelaskan konsekuensi jangka panjang dalam pengaruh julukan sebagai deviasi pada identitas sosial seseorang.

Pada prinsipnya, penjulukan sosial terbentuk dengan sistematisasi sebagai berikut:

(1) Orang-orang dapat terlibat dalam perilaku yang memiliki risiko untuk dijuluki sebagai penyimpangan, kenakalan, atau kriminal;

(2) Ada dua jenis perilaku devians:

Primary deviance, yaitu mengasumsian bahwa tiap orang memiliki kesempatan yang sama untuk melanggar norma-norma dan peraturan sosial dengan ataupun tanpa alasan yang jelas.

Secondary deviance, yaitu setelah perilaku menyimpang dilakukan dan diberikan label sebagai trouble maker atau pembuat masalah, maka julukan ini akan melekat dan mengarahkannya untuk melakukan penyimpangan lebih banyak (ini yang menjadi fokus teori penjulukan);

(3) Secondary deviance terbentuk setelah masyarakat/sosial peduli dan berhati-hati terhadap perilaku penyimpangan pertama (primary deviance);

(4) Hanya setelah julukan melekat, maka pergerakan perilaku kriminal justru makin meningkat.

Teori penjulukan penting, karena teori ini berangkat dari asumsi bahwa tidak ada suatu tindakan pun yang secara intrinsik kriminal. Definisi kriminalitas ditetapkan oleh pihak yang berkuasa, melalui perumusan hukum dan interpretasi oleh polisi, pengadilan, dan lembaga-lembaga pemasyarakatan (Giddens , 1991: 129-130 dalam Mulyana, 2004:162). Menurut teori ini, proses penjulukan ini demikian dahsyatnya sehingga korban-korban pendefinisian salah kaprah ini tidak dapat menahan pengaruhnya. Karena berondongan julukan yang bertentangan dengan pandangan mereka sendiri, citra diri asli mereka sirna, digantikan citra diri baru yang diberikan orang lain. Meskipun, pada awalnya hal tersebut bertentangan dengan keinginan mereka. Dampak penjulukan ini lebih hebat terutama bagi orang yang berada pada posisi yang lemah. Dengan kata lain, teori ini menyatakan bahwa bagaimana identitas diri dan perilaku dipengaruhi atau diciptakan oleh sistem sosial. Dalam teori penjulukan, ada satu pemikiran dasar, di mana pemikiran tersebut menyatakan seseorang yang diberi label sebagai seseorang yang devians dan diperlakukan 
seperti orang yang devians akan menjadi devians.

Dalam sosiologi dan kriminologi, teori ini memfokuskan pada tendensi linguistik yang mayoritas memiliki label negatif daripada keadaan sebenarnya atau seperti deviasi dari normanya dan ini terkait dengan konsep diri dan stereotyping. Sebagai terapan dari fenomenologi, hipotesis teori ini menyatakan bahwa label yang diberikan akan mempengaruhi perilakunya, sebagian besar penerapan ini memiliki label dan stigma yang negatif(seperti kriminal), meningkatkan perilaku yang menyimpang dan menjadi suatu konsep diri. Sebagai contoh, seorang individu yang diberi label memiliki kesempatan yang kecil untuk mengonfirmasikan arti sebenarnya dari penilaian (pelabelan) tersebut.

Dalam pandangan sosiologi, penjulukan berkaitan dengan seseorang yang kemudian diberi label spesifik diagnosa penyakit mental sehingga mengakibatkan penyimpangan perilaku. Sehingga, orang ini kemudian seterusnya mendapat perawatan medis sebagai orang yang "sakit mental".

Ada dua jenis masyarakat yang melakukan penjulukan terhadap orang lain:

(1) Hard Labeling. Adalah orang-orang yang percaya bahwa sakit mental itu tidak ada. Itu hanyalah penyimpangan perilaku dari norma masyarakat yang menyebabkan orang-orang percaya adanya sakit mental. Hingga sebenarnya, sakit mental merupakan penyakit hasil dari konstruksi sosial dan kelainan psikotis yang sebenarnya tidak ada.

(2) Soft Labeling. Adalah orang-orang yang percaya bahwa sebenarnya sakit mental itu ada, dan memang benar ada. Tidak seperti pendukung hard labeling, soft labeling mendukung percaya bahwa sakit mental tidak merupakan hasil konstruksi sosial.

Secara ringkas, John Hamlin menyatakan bahwa asumsi dasar teori penjulukan dapat dituliskan sebagai berikut:

(1) Merupakan aplikasi dari teori interaksi simbolik dari George Herbert Mead yang memfokuskan pada perilaku menyimpang (deviasi) dan proses-proses dari khalayak sosial yang menciptakan deviasi dan devians (orang yang berperilaku menyimpang) yang menyebabkannya berperilaku sebagaimana yang dilabel oleh masyarakat.

(2) Merupakan sebuah proses transfer dan pengambilan tempat antara perilaku dan pelaku, label dengan mudah ditransfer dari satu ke yang lainnya (Frank Tannenbaum, Crime and Community, 1983).

(3) Label berhubungan dengan bagaimana norma dan perilaku dibentuk, namun begitu mudah hubungan itu di putuskan (Howard S. Becker).

(4) Merupakan sebuah teori yang mengubah identitas seseorang, dengan mengubah perilaku primernya menjadi perilaku sekunder (Edwin M. Lemert).

(5) Tidak semua orang yang mendapatkan label akan mendapatkan dampak yang sama. Beberpa orang mungkin suka, namun yang lain tidak. Ini disebut dengan Moral Enterpreuners (Howard S. Becker).

(6) Ada akibat yang berbahaya bagi korban penjulukan.

(7) Teori penjulukan tidak mengkhususkan dengan julukan apa yang diberikan pertama kali namun bagaimana orang bertahan dengan penjulukan yang diberikan.

\section{Empat Elemen Teori Penjulukan}

Menurut Becker dan Lemert, ada empat elemen dasar dari teori penjulukan, yaitu:

(1) Label sosial diberikan pada perilaku tertentu

Teori penjulukan menyatakan bahwa perilaku abnormal pada faktanya diciptakan oleh harapan sosial (social expectations). Ini berarti bahwa kondisi sosial menciptakan norma-norma dan aturan-aturan yang mengharuskan setiap individu untuk mengikutinya, dan bila tidak mengikutinya maka akan didefinisikan sebagai perilaku yang abnormal. Teori ini mempelajari bagaimana konteks sosial dan faktor sosial berpengaruh pada diagnosis perilaku abnormal. Thomas Scheff $(1984)^{5}$, orang yang mendukung teori ini, menyebutkannya sebagai kesalahan adaptasi aturan sosial. Dia mengungkapkan bahwa kondisi seseorang yang mengalami penyimpangan mental akan semakin 
menderita setelah mereka di beri label "gila".

(2) Kriminalitas kebanyakan disebabkan

oleh peraturan sosial

Ketika peraturan di anggap sebagai sesuatu yang harus ditaati, akan tergantung pada signifikansi moral masyarakatnya. Sebagai contoh, perilaku seks bebas bukanlah suatu hal salah di negara maju, seperti Amerika ataupun negara Eropa lainnya. Namun, perilaku seks bebas, misalnya dalam melakukan hubungan sebelum menikah, termasuk dalam kategori perzinahan di negara Islam, dan ini disebut sebagai pelanggaran bahkan pelakunya dicap sebagai pelaku kriminal.

(3) Kontrol sosial memperburuk masalah kriminal

Teori penjulukan meyakini bahwa penjulukan dan reaksi yang keluar sebagai "kriminal" diantisipasi dengan cara yang negatif, sehingga menyebabkan masalah kriminalitas menjadi semakin buruk. Teori ini meyakini bahwa campur tangan sistem peradilan terhadap kriminalitas sudah terlalu jauh, dan ini sangat berbahaya, sehingga justru akan menjadi penyakit kriminal yang inheren dengan diri seseorang. Broadly ${ }^{6}$ mendefinisikan, kriminal sebagai penolakan terhadap konsep legalitas dari arti kejahatan itu sendiri. Teori penjulukan memiliki konsep yang kritis terhadap perilaku kriminal dan pelanggaran hukum. Untuk memastikan, para ahli sepakat bahwa seperti pembunuh, misalnya memang patut di cela, namun argumentasi ini tidak membahayakan lantas membuat orang bertindak kriminal. Walaupun, pada akhirnya, ternyata penjulukan dapat menyebabkan aksi yang bervariasi dari situasi ke situasi. Masyarakatlah yang menyebabkan suatu perilaku dijuluki sebagai tindakan kriminal. Ini disebut sebagai titik pandang konstruksi sosial di mana variasi kriminalitas kian berubah dari situasi ke situasi yang lain, melewati ruang dan waktu. Ini juga disebut sebagai titik pandang interaksi simbolik di mana kriminalitas didefiniskan dengan simbol dan makna yang dikomunikasikan antara seseorang dengan orang lain.

Perilaku menyimpang bukan merupakan perlawanan terhadap norma, tetapi berbagai perilaku yang berhasil didefinisikan atau dijuluki menyimpang. Deviasi atau penyimpangan tidak inheren dalam tindakan itu sendiri tetapi merupakan respon terhadap orang lain dalam bertindak. Penjulukan itu sendiri menghasilkan atau memperkuat penyimpangan. Respon orang-orang menyimpang terhadap reaksi sosial menghasilkan penyimpangan sekunder yang mana mereka mendapatkan citra diri atau definisi diri (self-image or self definition) sebagai seorang yang secara permanen "terkunci" dengan peran orang yang menyimpang. Penyimpangan merupakan outcome atau akibat dari kesalahan sosial dan penggunaan kontrol sosial.

(4) Adanya kekuatan yang saling berhubungan antara orang yang diberi julukan dengan penjulukan yang diberikan.

Teori penjulukan melihat adanya bahwa kadang-kadang manusia adalah korban tak berdaya dari interpretasi atau label yang diberikan sorang lain sedemikian rupa sehingga identitas sosial mereka dapat dipaksakan kepada mereka sekalipun bertentangan dengan kemauan mereka. Pengamatan atau kasus-kasus bekas narapidana di negara kita menunjukkan bahwa julukan yang diberikan masyarakat kepada bekas narapidana mengakibatkan sebagian dari bekas narapidana itu menginternalisasikan julukan tersebut sehingga menjadi bagian dari citra diri dan kesadaran mereka.

Penjulukan sebenarnya problematik. Benar atau salah penjulukan itu, reaksi yang diberikan objek yang dijuluki terhadap orang lain "membenarkan" penjulukan tersebut. Maka, penjulukan ini telah dibuatnya sendiri. Kasus ini menjadi realitas bagi si penjuluk dan orang yang dijuluki. Pernyataan klasik dari seorang sosiolog ternama, William I Thomas, "if men define situations as real, they are real in their consequences" masih aktual. Manusia memutuska melakukan sesuatu berdasarkan penafsiran atas dunia sekeliling mereka.

Peggy Thoits menyebutkan dalam artikelnya bahwa orang yang dijuluki dengan "sakit mental" dan digambarkan sebagai seorang yang tidak dapat diprediksi, berbahaya, dan tidak bisa mengurus diri sendiri. Ia juga mengatakan bahwa seseorang yang diberi label seorang devians dan diperlakukan sebagai seorang devians, maka dia 
akan menjadi devians (Thoits, 1999:134).

Pernyataan ini dapat diartikan dalam dua hal, bahwa proses yang terjadi adalah, pertama, berkaitan dengan self-labeling (penjulukan pada diri sendiri), dan yang kedua proses bagaimana masyarakat memperlakukan mereka berdasarkan label yang mereka dapatkan. Sehingga, sebagai contoh, bila masyarakat menjuluki bahwa seseorang yang dijuluki sebagai orang yang tidak dapat diprediksi, berbahaya, dan tidak mampu mengurus diri sendiri, di juluki sebagai orang yang sakit mental, padahal ia tidak sakit mental, maka yang tejadi adalah, orang tersebut bisa benar-benar sakit mental.

Adanya kekuatan yang saling berhubungan antara orang yang diberi julukan dengan penjulukan yang diberikan, yaitu, pertama, master status. Dalam teori penjulukan, label dominan seringkali lebih mengarah pada suatu keadaan yang disebut master status.

Once someone has been successfully labelled as criminal or deviant, the label attached may become the dominant label or "master status" which is seeen as more important than all the other aspects of the person. He or she becomes a 'hooligan' or 'thief' rather than a father, mother, or friend. Each label carries ith it prejudices and images and this may lead to others interpretting the behavior of the labelled person in a particular way.

Master status adalah label yang dicantelkan yang biasanya terlihat sebagai karakteristik yang lebih atau paling penting menonjol dari aspek lainnya pada orang yang bersangkutan. Bagi sebagian orang julukan penyimpangan telah ditetapkan atau biasa dikenal dengan konsep diri, mereka akan menerima diri mereka sebagai devians. Bagi para devians julukan tersebut menyulitkan. Mereka akan mulai bertindak selaras dengan julukan tersebut. Dampaknya mungkin keluarga, teman, atau lingkungannya tidak mau bergabung dengan yang bersangkutan. Dengan kata lain, bahwa orang mengalami stigma sebagai devians dengan berbagai konsekuensinya, dan akan dikeluarkan dari kontak hubungan-hubungan sosial yang ada. Kondisi seperti ini akan sangat menyulitkan yang bersangkutan untuk menata identitasnya dari seorang yang bukan menympang. Sehingga berakibat bahwa dia akan melihat dirinya secara mendasar sebagaimana julukan yang diberikan.

Kedua, Deviant Career, dimana konsep dirinya mengacu pada suatu tahapan ketika si devians mulai menjadi devians secara penuh. Kai T. Erikson ${ }^{7}$ menyatakan bahwa penyimpangan bukanlah satu bentuk perilaku yang inheren tetapi merupakan pemberian dari anggota lingkungan yang mengetahuinya dan menyaksikan tindakan mereka secara langsung maupun secara tidak langsung.

\section{Konstruksi Sosial Teori Penjulukan di Media Massa}

Konstruksi sosial dari perilaku devians memegang peranan penting dalam proses melabel atau menjuluki yang terjadi di masyarakat. Proses ini tidak hanya melibatkan penjulukan pada perilaku kriminal devians, di mana perilakunya tidak sesuai dengan norma sosial, namun juga merefleksikan stereotip dan stigmatisasi dari perilaku menyimpang. Tampilan media massa yang mempresentasikan bagaimana seorang yang mendapat julukan sakit mental atau mengalami penyimpangan perilaku sangat tergantung pada bagaimana masyarakat memiliki persepsi tentang hal itu. Penggunaan media massa dalam memberikan julukan kepada seseorang sangat sering kita lihat sekarang ini, dan bagaimana julukan tersebut memberikan pengaruh pada orang tersebut. Satu peran yang pasti, yang dilakukan media massa dalam mengonstruksi teori penjulukan ini adalah dengan mendramatisasi penayangan ataupun informasi dengan menciptakan karakter perilaku menyimpang yang harus ditakuti ataupun justru dikasihani.

Sehingga, media massa atau pers, berperan aktifdalam menyebarkan penjulukan tersebut. Pers merupakan lembaga kemasyarakatan dan merupakan subsistem dari sistem kemasyarakatan di mana ia berada bersama-sama dengan subsistemsubsistem lainnya. Dengan demikian, maka pers tidak hidup sendiri, melainkan memengaruhi dan 
dipengaruhi oleh lembaga-lembaga kemasyarakatan lainnya. Dengan posisi yang demikian, pers selalu dituntut untuk objektif, apalagi utnuk mengetengahkan konflik-konflik yang sensitif sifatnya. Menurut Olieb ${ }^{8}$, Donahue, dan Tichenor, dalam situasi konflik, fungsi media massa adalah (1) mengeliminasi konflik dan mengedepankan konsesus, serta mengedepankan dan menonjolkan konflik

Agaknya fungsi kedua inilah yang lebih tampak dianut oleh pers Indoesia sekarang. Tidak berlebihan bila posisi dan peran pers sekarang tengah berada dalam posisi watch dog (anjing penggonggong) dan bukan lagi sebagai guard dog (anjing penjaga) bagi penguasa seperti pada masa Orde Baru, di mana pers berfungsi untuk meredam opini publik, melegitimasi keputusan politik penguasa, dan mementingkan kepentingan diri sendiri.

Media berperan penting dalam pembentukan, mobilisasi, dan pemeliharaan konflik antarkelompok. Peliputan atas isu, peristiwa, atau pelaku konflik mencerminkan distribusi kekuasaan dalam sistem sosial, khususnya kepentingan kelompok dominan dalam sistem sosial tersebut. Dalam konteks ini, secara selektif, media berfungsi mempercepat, memperlambat, menjelaskan, atau meredefinisikan konflik sosial.

Berita yang disajikan pers, meskipun diklaim objektif, tetap saja mengandung bias. Karena, bahasa itu sendiri (termasuk bahasa gambar) merupakan serangkaian pesan yang diciptakan oleh orang-orang yang juga pernah hidup dalam historisitas tertentu. Semua perangkat nilai yang telah mereka serap, ditambah kodisi fisiologis dan psikologis mereka yang situasional, turut memengaruhi perumusan dan penyampaian berita.

Pada dasarnya, bahasa (kata-kata) itu tidak netral. Di dalamnya, terdapat muatan-muatan pribadi, sosio kultural, atau ideologis meski bersifat subtil. Karena itu, tidak ada berita yang objektif dalam pengertian murni atau mutlak. Berita merupakan rekonstruksi pikiran wartawan (institusi pers) mengenai suatu peristiwa atau pernyataan yang telah lewat.

Wartawan atau redaksi akan memilih kata-kata tertentu untuk menyiratkan seseorang atau peristiwa. Namun, pada saat itu mereka juga "tidak objektif” dengan meniadakan sifat-sifat lain yang sebenarnya melekat pada orang atau peristiwa tersebut. Walhasil, berita juga adalah opini. Demikian juga penjulukan yang dilakukan pihak pers dalam bentuk kata-kata oleh media cetak atau gambar oleh media televisi. Narasi atau penjulukan tersebut akan ditafsirkan oleh pembaca atau pemirsa dengan cara mereka sendiri.

Opini publik yang terbentuk, menurut para ahli, adalah cermin dari stuktur sosial dan kebudayaan dari masyarakatnya. Opini publik bukan bagian dari realitas way of life masyarakatnya, bukan pula serpihan ideologi. Opini publik pun tidak dapat diidentifikasi sebagai subsistem dari sistem kekuasaan, baik dalam arti power politics maupun dalam arti political power.

Di sinilah letak critical point (titik genting) dari pengertian opini publik pada umumnya. Sebab, jika di satu pihak opini publik itu sering ditafsirkan sebagai pendapat umum (public opinion), namun di lain pihak, opini publik tidak dianggap sama dengan kumpulan opni dari sejumlah individu. Penilaian demikian tentang opini publik merupakan terminal dan sekaligus memberikan peluang bagi penyebaran gagasan demokratis, paling tidak, di pengertian tadi, opini publik kemudian ditafsirkan sebagai hasil dialog dinamis dari sistem sosial di lingkungannya yang bukan hanya berlangsung terus-menerus, tetapi juga terselenggara secara tebuka dan dinamis.

Seperti dikatakan Peter Dahlgren, realitas sosial menurut pandangan konstrukvis (fenomoenologis) setidaknya sebagian adalah produksi manusia, hasil proses budaya, termasuk penggunaan bahasa. Makna adalah suatu konstruksi, meskipun terkadang rentan dan muskil dan salah satu cara mendasar kita dalam menghasilkan makna mengenai dunia nyata adalah lewat media massa

Peristiwa-peristiwa yang ditangkap media massa, berita sekalipun, jelas bukan peristiwa sebenarnya, baik dilihat dari urutannya maupun durasinya. Narasi media massa merupakan seleksi peristiwa yang sudah direproduksi dalam bentuk 
yang artifisial. Narasilah yang menghubungkan peristiwa sebenarnya dengan khalayak. Dan, narasi tidak sekedar menyampaikan, melainkan juga menciptakan makna.

Julukan-julukan tertentu jelas merupakan salah satu pendefinisian untuk menciptakan ralitas baru mengenai peristiwa atau orang yang didefinisikan. Narasi disini meliputi bukan hanya bersifat fiksi atau jurnalistik, bahkan juga semu narasi yang diklaim sebagai objektif seperti dalam konteks hukum, medis, dan ilmiah sosial.

Pada saat seseorang telah tergantung pada hubungan-hubungan yang bersifat menyimpang dan mulai menggunakan tindakan menyimpang sebagai alat pelindung terhadap tekanan masyarakat konvensional yang menjuluki seseorang sebagai penyimpang, maka penyimpangan menjadi fokus perhatian utama reorganisasi perjalanan hidup orang itu.

Berbagai studi penelitian yang menguji kebenaran teori penjulukan saling bertentangan dan tidak meyakinkan. Kebanyakan kelompok primer (kelompok yang anggotanya melakukan tindakan menyimpang) menolak untuk menyingkirkan anggota mereka yang menyimpang. Mereka justru mencari jalan agar penyimpang tersebut dapat kembali menyesuaikan diri. Kenyataan empiris menunjukkan bahwa dalam keadaan tertentu, penjulukan mendorong timbulnya penjulukan selanjutnya. Sebagai kesimpulan dapat dikatakan bahwa penjulukan kadang kala meningkatkan tetapi kadangkala juga mengurangi timbulnya penyimpangan.

Dalam buku Raising A Happy Child ${ }^{9}$, banyak ahli yang setuju, bahwa bagaimana seseorang memandang dan merasakan dirinya sendiri akan menjadi dasar orang tersebut beradaptasi sepanjang hidupnya. Anak yang memandang dirinya baik akan mendekati orang lain dengan rasa percaya dan memandang dunia sebagai tempat yang aman, dan kebutuhankebutuhannya akan terpenuhi. Sementara anak yang merasa dirinya tidak berharga, tidak dicintai akan cenderung memilih jalan yang mudah, tidak berani mengambil risiko dan tetap saja tidak berprestasi. Bagi banyak orang, termasuk anakanak, pengalaman mendapatkan label tertentu (terutama yang negatif) memicu pemikiran bahwa dirinya ditolak. Pemikiran bahwa dirinya ditolak dan kemudian dibarengi oleh penolakan yang sesungguhnya, dapat menghancurkan kemampuan berinteraksi, mengurangi rasa harga diri, dan berpengaruh negatif terhadap kinerja seseorang dalam kehidupan sosial dan kehidupan kerjanya.

\section{Catatan Akhir}

http://en.wikipedia.org/wiki/W._I._Thomas

2 Becker, H. 1963. Outsiders: Studies in the Sociology of Deviance. New York: The Free Press.

3 http://www.pineforge.com/newman 4 study/resources/ tannenbaum 1.htm

4 http://books.google.co.id/books?hl=en\&id= yPCDLAuXZ14C\&dq $=$ edwin $+\mathrm{m}+$ lemert \&printsec $=$ frontcover\&source $=$ web\&ots $=$ TPCi3hcmb4\&sig $=V P 2 C Q-$ uuUESe0M8208a1X2HO_og \#PPP1,M1

5 http://www.academyanalyticarts.org/scheff.htm

6 http://www.financeproject.org/publications/ ThinkingBroadlyCTS.pdf

7 http://www.yale.edu/sociology/faculty/pages/erikson/

8 http://books.google.co.id/books? id= B 0 A B A A A A A A \& p g = PA $95 \& 1 \mathrm{pg}=$ PA $95 \&$ d q $=$ O li e b \& s o u r c e $=$ w e b \& o t s $=4 \mathrm{p} \mathrm{OEg} \mathrm{T} \mathrm{B} \mathrm{m} \mathrm{X} \mathrm{b} \mathrm{\&} \mathrm{s} \mathrm{i} \mathrm{g} \mathrm{=} \mathrm{E} \mathrm{A} \mathrm{r} 4$ b W W i ntI16KOTAxEDBaK8jg\&hl=en\#PPA90,M1

9 http://www.tips-to-organize-life.com/raising-a-happychild.html

\section{Daftar Pustaka}

Ali, Novel. 1999. Peradaban Komunikasi Politik Potret Manusia Indonesia. Bandung: PT Remaja Rosdakarya. 
Effendy, Onong U. 1981. Dimensi-Dimensi Komunikasi. Bandung: Penerbit Alumni.

Horton, paul B., \& Hunt, Chester L. 1999. Sosiologi. Jakarta: Penyunting Aminudin Ram dan Titi Sobari. Penerbit Erlangga.

Horwitz \& Scheid. A Handbook for the Study of Mental Health: Social Contexts, Theories, and Systems. Cambridge; New York, NY. 1999. Link B.G. \& Phelen J.C. The Labelling Theory of Mental Disorder (II): The Consequences of Labeling. dalam http://www.everything2.com/ index.pl?node id=784096

Mulyana, Deddy. 2002. Metodologi Penelitian Kualitatif. Bandung: PT Remaja Rosdakarya.

. 2004. Komunikasi Populer

Kajian Komunikasi dan Budaya Kontemporer. Bandung: Pustaka Bani Quraisy.

-_-_-_-_-_-_ 1999. Nuansa-Nuansa Komunikasi. Bandung: PT Remaja Rosdakarya.

1999. "Teori Penjulukan Pers, Pers dan Konstruksi Sosial." Seminar Nasional ISKI. 2 Oktober.

Mead, George Herbert. 1934. Mind, Self, and Society, ed. C.W. Morris. Chicago: University of Chicago.
Thoits, Peggy A. 1999. Sociological Approaches to Mental Illness. Pp. 121-138 in A Handbook for the Study of Mental Health, edited by Allan V. Horwitz and Teresa L. Scheid. Cambridge University Press.

\section{Sumber Lain:}

http://en.wikipedia.org/wiki/labeling theory

http://bitbucket.icaap.org

http://www.freeessays.cc/db/44/smu105.shtml

http://www.d.umn.edu/cla/faculty/hamlin/2311/ labeling.html

http://www.rci.rutgers.edu

http://www.bookrags.com/wiki/Labeling theory:

http://www.hewett.norfolk.sch..uk/curric/soc/ crime/labeling.htm

http://www.d.umn.edu/cla/faculty/hamlin/2311/ labeling.html.

http://www.le.ac.uk/education/resources/SocSci/ labelling.html)

ht t p : / / w w w. everything 2. com/ index.pl?node id $=784096$

http://www.e-psikologi.com/anak/160502.htm 
